\title{
Pelatihan Metode Pembelajaran Bahasa Inggris bagi Para Relawan Pengajar
}

\author{
Erna Megawati ${ }^{*}$ \\ ${ }^{1}$ Universitas Indraprasta PGRI, Jl. Nangka Raya No. 58 C Jakarta Selatan, DKI Jakarta, Indonesia, 12530 \\ *Email: megawatie45@yahoo.com
}

\begin{abstract}
Abstrak
Penggunaan metode pembelajaran yang tepat akan membantu dalam mencapai tujuan pendidikan dalam jenjang manapun. Data statistik menunjukkan tingginya angka buta aksara di Indonesia mendorong semua anggota masyarakat yang terdidik untuk turun dan melayani anggota masyarakat lain yang membutuhkan. Kegiatan ini bertujuan untuk memberikan pelatihan mengenai metode pembelajaran bahasa Inggris yang dapat digunakan oleh relawan pengajar di kampung Mulyasari yang berdedikasi memberantas buta aksara. Metode pelaksanaan kegiatan ini pelatihan dan pemberian contoh. Hasil kegiatan ini menunjukkan bahwa metode pembelajaran bahasa Inggris yang dinilai cocok dengan karakteristik peserta didik di Mulyasari adalah TPR (Total Physical Response).
\end{abstract}

Kata kunci: metode pembelajaran, pendidikan, relawan, buta aksara

\begin{abstract}
The usage of language learning methods is believed to help in achieving education goals in every level. Statistic has shown if the number of societies who are illiterate still very high which encourage the other members who are educated to serve the others. This activity is aimed to give training of learning methods to education volunteer in Kampung Mulyasari. The activity was conductes using methods such as training and demonstrating. The result shows if TPR (Total Physical Response) is the most appropriate model which fits in to the learners in Mulyasari.
\end{abstract}

Keywords: methods to education, education, volunteer, illiterate

Format Sitasi: Megawati, E. (2020). Pelatihan Metode Pembelajaran Bahasa Inggris bagi Para Relawan Pengajar. Jurnal SOLMA, 09(1), 01-13. Doi: http://dx.doi.org/10.29405/solma.v9i1.3042

Diterima: 06 Februari 2019 | Revisi: 31 Januari 2020 | Dipublikasikan: 30 April 2020

(C) 2020 Oleh authors. Lisensi Jurnal Solma, LPPM-Uhamka, Jakarta. Artikel ini bersifat open access yang didistribusikan di bawah syarat dan ketentuan Creative Commons Attribution (CC BY) license. (http://creativecommons.org/licenses/by/4.0/).

\section{PENDAHULUAN}

Pendidikan merupakan hak bagi seluruh warga negara Indonesia yang dijamin dalam Undang-undang nomor 20 tahun 2003 tentang Sistem Pendidikan Nasional. Dalam Undang-undang dinyatakan bahwa pendidikan adalah usaha sadar dan terencana untuk mewujudkan suasana belajar dan proses pembelajaran agar peserta didik secara aktif mengembangkan potensi dirinya untuk memiliki kekuatan spiritual keagamaan, 
pengendalian diri, kepribadian, kecerdasan, akhlak mulia, serta keterampilan yang diperlukan dirinya, masyarakat, bangsa dan Negara (UU No. 20 Tahun 2003). Hal tersebut menggambarkan bahwa pendidikan memungkinkan individu untuk dapat mengembangkan potensi dirinya dalam berbagai aspek kehidupan.

Demikian pentingya peran pendidikan juga ditegaskan oleh Menteri Pendidikan Nasional M. Nuh bahwa mulai tahun ajaran 2011/2012, pendidikan berbasis karakter akan dijadikan sebagai gerakan nasional, mulai dari Pendidikan Anak Usia Dini (PAUD) sampai dengan Perguruan Tinggi, termasuk di dalamnya pendidikan non-formal dan informal (Kosim, 2012). Hal tersebut jelas mengindikasikan jika pendidikan merupakan isu nasional, terutam pendidikan berbasis karakter.

Pendidikan juga merupakan investasi modal manusia (human capital) yang berharga selain investasi berupa fisik. Lebih jauh Dwi Atmanti (2005) mengorelasikan antara investasi sunber daya manusia melalui pendidikan terhadap pertumbuhan ekonomi. Semakin tinggi kualitas sumber daya manusia maka produktivitas serta efisiensi suatu negara juga akan semakin meningkat. Dengan demikian hubungan antara pendidikan dengan perekonomian berbanding lurus.

Sungguh disayangkan ketika pendidikan belum dapat dirasakan oleh semua warga masyarakat karena berbagai faktor. Sudarsana (2018) menyebutkan bahwa salah satu faktor yang menghambat meratanya pendidikan ke seluruh wilayah adalah mahalnya biaya pendidikan. Indonesia juga disinyalir mengalami krisis sumber daya manusia sebagai akibat belum terpenuhinya standar pendidikan.

Sebuah harapan muncul ketika mulai timbulnya kepedulian anggota masyarakat yang terdidik datang untuk melayani masyarakat melalui jalur pendidikan nonformal. Sudarsana (2018) menyatakan bahwa kegiatan-kegiatan non-fomal hendaknya membawa kemajuan yang berarti. Pendidikan nonformal di negara berkembang seperti Indonesia menjadi satu alternatif dalam melayani pendidikan bagi banyak petani, pekerja, usahawan kecil, dan anggota masyarakat lain yang tidak terjamah oleh pendidikan formal karena berbagai faktor.

Faktor yang turut memengaruhi aksesibilitas pendidikan diteliti oleh Perdana (2015) di antaranya adalah 1) Anak laki-laki memiliki probabilita bersekolah lebih tinggi jika dibandingkan dengan anak perempuan; 2) Anak yang tinggal di perkotaan memiliki probabilita bersekolah lebih tinggi jika dibandingkan dengan anak yang tinggal di perdesaan; 3) Anak dengan latar belakang pendidikan ibu hingga jenjang pendidikan 
menengah dan pendidikan tinggi memiliki probabilita bersekolah yang lebih tinggi jika dibandingkan anak dengan latar belakang pendidikan Ibu hingga jenjang pendidikan dasar; 4) Anak dengan jarak ke sekolah yang dekat memiliki probabilita bersekolah yang lebih tinggi jika dibandingkan anak dengan jarak ke sekolah yang jauh. Berbagai faktor tesebut butuh untuk disolusikan oleh smeua warga negara Indonesia dan bukan hanya menggantungkan penyelesaian pada pemerintah pusat dengan berbagai keterbatasannya.

Upaya yang dilakukan pemerintah dalam meratakan pendidikan adalah dengan jalan mencanangkan satu gerakan nasional pemberantasan buta aksara sejak 16 Agustus 1978. Berdasarkan data Education for All Global Monitoring Report tahun 2005 Sahputra (2014), populasi buta huruf di Indonesia masih berkisar 18,4 juta orang yang berarti merupakan negara yang ke-8 dengan populasi buta huruf terbesar di dunia. BPS (2006), angka buta aksara penduduk Indonesia mencapai 12,8 juta orang atau 0,05 persen dari total jumlah penduduk, dan angka tersebut meningkat pada kelompok umur dewasa (15 tahun keatas) menjadi 8,4 persen dari total penduduk pada kelompok umur tersebut. Perempuan menempati posisi lebih tinggi pada angka kebutaaksaraan kelompok usia 15-44 tahun, dengan persentase sebesar 4,8 persen untuk perempuan, dan 2,9 persen untuk laki-laki. Hal tersebut merupakan kenyataan yang memrihatinkan mengingat kayanya sumber daya alam Indonesia yang tidak diiringi dengan kemampuan sumber daya manusianya.

Tantangan nyata lain yang dihadapi anak bangsa adalah implementasi MEA (Masyarakat Ekonomi ASEAN). MEA membuka arus perdagangan barang, jasa dan juga tenaga kerja professional. Hal tersebut tentu menuntut kesiapan SDM bangsa Indonesia dalam segala lini. Menurut Staf Khusus Menteri Tenaga Kerja dan Transmigrasi, Wuryandani (2014) MEA mensyaratkan adanya penghapusan aturan-aturan yang sebelumnya menghalangi perekrutan tenaga kerja asing. Dengan demikian, para pekerja kita harus bersaing dengan para pekerja asing yang datang ke Indonesia. Hal mutlak yang menjadi persiapan bagi SDM adalah persoalan bahasa. Bahasa Inggris sebagai lingua franca menjadi satu bahasa yang tidak bisa dihindari dalam usaha memertahankan dan meningkatkan SDM bangsa.

\section{MASALAH}

Berbagai cara dilakukan oleh seorang pendidik agar peserta didik dapat memahami bahasa Inggris secara mudah dan efisien. Permasalahan yang muncul di Desa Mulyasari adalah sulitnya akses menuju lokasi. Untuk mencapai lokasi, tim harus berjalan menaiki 
bukit kecil selama kurang lebih 2 jam. Hal ini juga yang menjadi kendala pengadaan pengajar di desa tersebut. Fasilitas yang dimiliki desa untuk belajar hanya berupa aula sederhana yang dibangun atas biaya pribadi seorang tokoh yang peduli pendidikan yang juga merangkap juga sebagai pengajar di kelompok belajar tersebut. Kendala muncul ketika tokoh tersebut berhalangan untuk mengajar maka pembelajaran ditiadakan. Atas inisiatif satu komunitas yang bernama 1001 Ilmu di bawah arahan Pak Wisnu, ada sekitar 30 relawan yang tergabung dan berdedikasi dalam komunitas relawan ini. Hasil wawancara menunjukkan bahwa banyak relawan yang hanya menggunakan metode pembelajaran konvesional dalam pengajaran bahasa Inggris. Metode yang tepat sangat diperlukan dalam penyampaian pembelajaran bahasa Inggris dikarenakan bahasa Inggris masih merupakan bahasa asing di Indonesia. Permasalahan yang menjadi perhatian komunitas ini adalah terjadi pada desa Sukamulya adalah masih ada anak-anak yang buta huruf. Kendala yang menghambat proses transfer pengetahuan adalah minimnya pengetahuan relawan pengajar akan metode pembelajaran yang dapat digunakan dalam pembelajaran Bahasa Inggris.

Adapun solusi yang tim tawarkan kepada relawan desa Sukamulya adalah pemberian pelatihan metode pembelajaran yang efektif dalam pengajaran Bahasa Inggris sehingga diharapkan Relawan dapat menggunakan metode yang tepat dalam pengajaran bahasa Inggris; Relawan dapat menggunakan variasi metode pengajaran untuk kelas umur yang sesuai; Relawan dapat menciptakan suasana belajar yang menyenangkan bagi para peserta didik.

\section{METODE PELAKSANAAN}

Waktu pelaksanaan kegiatan pengabdian kepada masyarakat ini adalah bulan Januari-April 2017 pada tanggal yang disepakati dengan mitra yaitu komunitas relawan 1001 Ilmu yang berlokasi di desa Sukamulya, Mulyasari, Bogor yaitu tim peneliti terdiri dari Erna Megawati, M. Pd sebagai ketua pelaksana, Azhari Ikhwati, S.Si., M.Pd. Sebagai anggota satu, dan Ila Nafilah S.S., M.Pd sebagai anggota dua. Kegiatan ini dilaksanakan di aula kampung Mulyasari, Desa Suka Mulya, Bogor. Metode yang digunakan dalam kegiatan pengabdian kepada masyarakat adalah metode pelatihan yang meliputi penyuluhan yang disertai contoh dan penugasan. 


\section{PEMBAHASAN}

\section{Pemaparan Materi}

Pelatihan diawali dengan menjelaskan kepada mitra mengenai metode-metode yang dapat digunakan dalam pembelajaran bahasa Inggris, yaitu:

1. Metode Grammar-Translation

Natsir \& Sanjaya (2014) menjelaskan bahwa metode Grammar Translation merupakan metode klasik yang digunakan dalam pengajaran bahasa klasik yaitu Latin dan Yunani. Sejatinya metode ini digunakan dalam rangka mengajarkan bahasa melalui pengajaran tata bahasa dan terjemahan. Dalam metode ini, peserta didik harus mengumpulkan pengetahuan mengenai bahasa asing yang akan dipelajari dengan jalan memelajari sejumlah peraturan tata bahasa dan menginterpretasikan teks menggunakan kamus. Tujuan metode ini adalah agar peserta didik menjadi terbiasa dengan tata bahasa pada bahasa sumber sehingga akan memudahkan peserta didik berbicara dan menulis dalam bahasa asing tersebut.

Langkah-langkah dalam penggunaan metode Grammar Translation adalah:
a. Kelas diajar menggunakan bahasa Ibu, dengan sedikit bahasa sasaran;
b. Kosa kata diajarkan dalam bentuk daftar kata secara terisolasi;
c. Pemberian penjelasan tata bahasa secara Panjang lebar;
d. Tata bahasa menjelaskan mengenai aturan penggabungan kata;
e. Pembacaan teks klasik yang rumit sejak awal pertemuan;
f. Tidak terlalu fokus pada isi teks.
g. Tidak terlalu memerhatikan pengucapan.

\section{Direct methods}

Metode pengajaran dengan direct method maksudnya adalah bahwa pengajaran bahas Inggris diberikan langsung dengan menggunakan bahasa sasaran (Inggris). Metode ini bertujuan agara peserta didik dapat menguasai kosa kata asing dengan cepat (Erwinandari, 2013).

Dalam mempraktikkan metode ini harus diperhatikan prinsip-prinsip dan prosedur yang ada, yaitu:

a. Kelas dikondisikan dalam bahasa target.

b. Vocabulary (kosakata) dan kalimat yang diajarkan merupakan kosa kata sehari-hari.

c. Tata bahasa diajarkan secara induktif. 
d. Pengajaran diberikan secara oral/lisan.

e. Vocabulary diajarkan dengan jalan menunjukkan objek atau gambar (dengan bahasa sasaran).

f. Pengajaran percakapan dan pemahaman bacaan (juga.

g. Fokus pada pembentukan/ pengoreksian pengucapan dan susunan kata.

\section{Audio Lingual}

Mart (2013) menyatakan bahwa bahasa pada awalnya merupakan sistem bunyi yang digunakan untuk komunikasi sosial dimana menulis merupakan sistem turunannya yang digunakan untuk merekan bahasa lisan. Lebih lanjut, Mart (2013) menjelaskan jika metode Audio Lingual memandang bahasa sebagai bentuk tingkah laku yang harus dipelajari mellaui bentuk kebiasaan ujaran yang tepat. Berdasarkan asumsi di atas, maka metode Audio Lingual mengajarkan bahasa sasaran sealami mungkin seperti pada awal bahasa tersebut diproduksi dan diterima pada lingkungan asli penutur.

Tujuan lain dari metode ini adalah: (1) untuk mengontrol pola-pola suara bentuk, dan perintah dalam bahas baru, (2) mengenali item-item kosakata yang terdapat pola tersebut, (3) arti atau maksud yaitu agar siswa dapat berbicara dengan bahasa tersebut seperti aslinya.

Prosedur pengajarannya adalah:

a. Pertama murid mendengarkan contoh dialog baik dari guru ataupun dari kaset yang berisi tentang struktur kata yang berhubungan dengan pelajaran kemudian murid mengulangi dialog tersebut secara individu kemudian bersama. Guru harus memperhatikan pada pengucapan, intonasi dan kelancaran bacaannya. Pemberian bisa diberikan secara langsung dan dialog tersebut dibahas sedikit demi sedikit, baris demi baris.

b. Dialog dipilih sesuai dengan situasi atau keadaan di mana murid tertarik dengan bacaan tersebut dengan mengubah sedikit struktur kata yang terdapat di dalamnya.

c. Beberapa struktur kata dalam dialog tersebut dipilih dan digunakan sebagai dasar untuk digunakan dalam pola kalimat yang berbeda. Kemudian dipraktekkan secara bersama-sama kemudian secara sendiri-sendiri. Penjelasan tentang grammar (pola kalimat) mungkin akan diberikan tapi terbatas.

d. Murid konsentrasi pada buku teks dan memperhatikan bacaan (temanya) tulisan 
atau kosakata dalam bacaan tersebut pada level awal. Menulis sedikit demi sedikit lebih diutamakan dari pada langsung mengopi kalimat yang telah dipraktekkan. Namun setelah kemampuan bertambah bisa langsung menulis beberapa struktur kalimat yang bervariasi yang akan mungkin digunakan dalam berbahasa.

e. Semua aktivitas tersebut bisa dilakukan dalam laboratorium bahasa di mana dialog dan bermacam-macam tugas lain yang lebih lengkap ada di dalamnya.

\section{Sillent Way Method}

Menurut Larsen \& Freeman (1986) karakteristik mengajar dari metode sillent way adalah siswa mulai belajar bahasanya melalui bangunan dasar dan suara bahasa. Ini semua diperkenalkan melalui tabel berwarna suara spesifik dari bahasa. Dengan mengandalkan pada suara yang sudah diketahui dari bahasa asli mereka, guru tinggal mengarahkan siswa untuk mengasosiasikan suara dari target bahasa dengan warna khusus yang dimaksud. Kemudian warna yang sama ini digunakan untuk membantu siswa belajar mengeja yang cocok dengan suara (melalui tabel kode warna fidel) bagaimana membaca dan mengucapkan kata dengan benar.

Guru harus mampu menciptakan situasi yang dapat memfokuskan perhatian siswa pada susunan bahasa. Situasi tersebut akan memberi mereka arahan untuk menangkap arti. Situasi itu sendiri kadang memerlukan penggunaan penyemangat tapi kadang tidak, itu semua secara tipikal hanya melibatkan satu susunan pada satu waktu. Dengan petunjuk tutur minimal siswa diarahkan memproduksi susunan bahasa. Guru bekerja bersama mereka, berusaha keras, mengucapkan kata-kata yang dapat dimengerti penutur asli dari bahasa target. Guru menggunakan kesalahan siswa sebagai bukti yang dapat menyatakan mana bahasa yang tidak jelas untuk siswa.

Guru berperan sebagai teknisi atau insinyur sehingga siswa yang dapat melakukan pembelajaran. Guru dapat mengandalkan apa yang telah diketahui oleh siswa, dapat memberikan bantuan yang diperlukan mereka, memfokuskan persepsi siswa, menekankan kesadaran mereka dan memberikan latihan-latihan untuk memastikan fasilitas mereka dengan bahasa. Guru harus merespek otonomi siswa dalam setiap usaha mereka untuk berhubungan dan berinteraksi dengan tantangan baru.

Di sisi lain, peran siswa adalah memanfaatkan apa yang mereka ketahui, membebaskan mereka dari tiap hambatan yang merintangi dengan memberi perhatian 
sepenuhnya pada tugas yang diberikan serta secara aktif mengajak mereka sama-sama menjelajah bahasa. Tak ada seorang pun yang dapat belajar untuk kita.

Evaluasi dari metode ini dapat diukur melalui belajar siswa tiap waktu. Selama mengajar dihubungkan dengan belajar siswa harus responsif terhadap kebutuhan belajar yang muncul. Diamnya guru akan membebaskannya untuk berada di antara siswanya dan waspada akan kebutuhan ini. Kebutuhan tersebut akan jelas bagi guru yang mengamati perilaku siswanya. Satu kriteria tentang ya tidaknya siswa belajar adalah kemampuan mereka untuk mentransfer apa yang telah pelajari ke dalam konteks baru.

\section{CLT (Communicative Language Teaching)}

Dimaksud dengan CLT adalah pengajaran bahas dengan pendekatan komunikatif. Jacobs \& Farrell (2003) menjelaskan jika pendekatan komunikatif membutuhkan seperangkat perencanaan dan toleransi yang kompleks untuk menganalisis kebutuhan peserta didik serta merancang tugas yang sesuai dengan kebutuhan tersebut.

Tujuan akhir pengajaran bahasa adalah kemampuan komunikatif para siswa. Lebih lanjut, Hymes memperjelas bahwa yang dimaksud mengembangkan kemampuan komunikatif para siswa adalah hal-hal yang harus diketahui dalam berkomunikasi sehingga mereka mampu memerankan komunikasi dengan menggunakan bahasa sasaran dengan tepat.

Prosedur pengajaran dengan CLT:

a. Presentasi dialog singkat yang didahului dengan motivasi sekitar situasi dalam dialog tersebut.

b. Praktik pengucapan ujaran-ujaran yang tepat, baik secara individu, kelompok, seluruh kelas separuh kelas yang biasanya dicontohkan terlebih dahulu oleh pengajar.

c. Mengajukan pertanyaan berdasarkan dialog yang dihubungkan dengan pengalaman sehari-hari dilanjutkan dengan variasi dari pengembangan kelas.

d. Memelajari ungkapan-ungkapan komunikatif yang dikontraskan dengan pengembangan yang mungkin telah dimiliki oleh para siswa.

e. Simpulan secara umum mengenai fokus penggunaan komunikasi yang ada dalam dialog tersebut baik yang sering digunakan dalam bahasa lisan ataupun tertulis.

f. Adanya percakapan bebas. 
g. Menirukan dialog tanpa teks di luar kelas yang dapat diperagakan berbentuk roleplay.

h. Memberi pekerjaan rumah tertulis ataupun lisan

i. Evaluasi dengan bentuk ungkapan yang diperagakan secara oral.

6. Total Physical Response (TPR)

Richards \& Rodgers (1986); Ikhwati \& Megawati (2018) mendefinisikan bahwa TPR merupakan metode yang dibangun dengan adanya koordinasi antara ujaran dan tidankan. Metode ini bertujuan mengajar bahasa melalui serangkaian aktifitas atas kegiatan fisik.

Peserta didik diharapkan dapat merespons perintah secara lisan, ketika peserta didik telah siap untuk berbicara, mereka menjadi orang yang melakukan perintah. Setelah siswa mulai berbicara, kegiatan ditambah dengan permainan.

Evaluasi dari metode ini adalah guru akan tahu secara langsung apakah siswa paham atau tidak dengan mengamati aksi mereka. Evaluasi formal dapat dilakukan secara sederhana dengan memberi intruksi secara individu pada peserta didik untuk melakukan serangkaian tindakan. Jika kemampuan peserta didik meningkat, performa mereka dalam melakukan instruksi bisa menjadi dasar evaluasi.

\section{Peer Teaching Method}

Megawati (2019) menjelaskan bahwa, metode pembelajaran peer teaching atau tutor sebaya menekankan pada adanya kesamaan kesempatan, saling membantu, tujuan yang sama dan kohesi kelompok. Metode ini diharapkan dapat merangsang peserta didik untuk mandiri serta terbuka dalam pembelajaran.

Metode ini memungkinkan peserta didik yang menjadi tutor mendapatkan pengetahuan baru serta mengasah pengetahuan yang dimilikinya dengan jalan mengajarkan pengetahuan tersebut. Bagi peserta didik yang dibimbing akan merasa lebih nyaman dan leluasa dalam mengonsultasikan kesulitannya karena yang menjadi tutornya merupakan kawan sebayanya. Tutor yang dipilih merupakan peserta didik yang mempunyai kemampuan mumpuni untuk mendampingi sejawatnya.

\section{Tanya Jawab}

Setelah materi disampaikan, para peserta pelatihan diberi kesempatan untuk menanyakan hal-hal yang kurang dapat dipahami dari pemberian materi.

Berikut ini pertanyaan yang diajukan oleh peserta: 
1. Metode yang mana yang paling tepat digunakan untuk pembelajaran di kampung Mulyasari?

Jawab:

Untuk mengetahui metode yang paling tepat untuk pembelajaran di kampung Mulyasari maka kita harus melakukan pendekatan Contextual Teaching Learning dengan student-centered, kemudian kita analisis. Setelah dianalisis maka kita dapat menentukan metode manakah yang paling memungkinkan untuk digunakan dalam pembelajaran di kampung Mulyasari.

2. Apakah metode-metode tersebut dapat diterapkan bagi anak-anak yang Buta Aksara seperti di Kampung Mulyasari?

Jawab:

Tentu saja. Metode-metode tersebut sudah merupakan satu kajian yang terbukti di berbagai kondisi termasuk untuk anak-anak dengan kondisi buta aksara sekalipun. Justru metode pembelajaran akan memudahkan pembelajar untuk mentransfer ilmu kepada peserta didik.

3. Hal apakah yang harus diperhatikan dalam pemberian metode pembelajaran bahasa Inggris?

Jawab:

Hal yang harus kita perhatikan dalam pemberian metode pembelajaran adalah karakteristik peserta didik karena hal tersebut yang menjadi acuan dalam penentuan metode yang akan digunakan.

\section{Penugasan}

Setelah sesi tanya jawab, para peserta pelatihan diberikan penugasan untuk mengukur pemahaman peserta. Para peserta pelatihan diminta untuk memparktikkan salah satu metode pembelajaran yang sudah disajikan. 


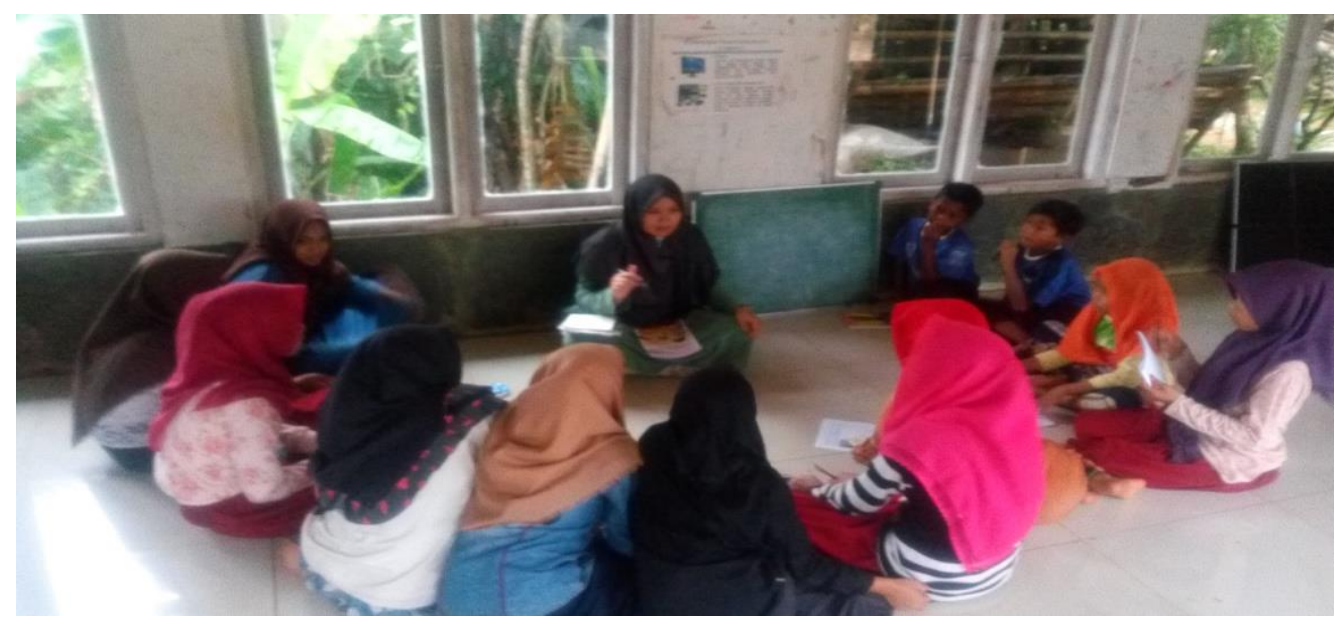

Gambar 1. Praktik Metode Pengajaran

Tabel 1. Persentase Hasil Pelatihan

\begin{tabular}{|c|c|c|c|}
\hline Sikap Relawan & Ya (\%) & Tidak (\%) & Jumlah \\
\hline $\begin{array}{l}\text { Pemahaman terhadap } \\
\text { Metode }\end{array}$ & 80 & 20 & 100 \\
\hline $\begin{array}{l}\text { Ketertarikan untuk } \\
\text { menerapkan metode }\end{array}$ & 100 & 0 & 100 \\
\hline Keaktifan dalam praktik & 90 & 10 & 100 \\
\hline
\end{tabular}

Tabel tersebut menggambarkan bahwa ada $80 \%$ Relawan pengajar masih belum memahami sepenuhnya tentang macam-macam metode pengajaran. Semua Relawan pengajar tertarik untuk menggunakan metode dalam pengajaran. 90\% Relawan pengajar belum memahami model pembelajaran yang dapat digunakan dalam pengajaran bahasa Inggris pada anak buta aksara. Namun, para Relawan pengajar belum aktif dalam kegiatan mengajar secara praktis.

\section{KESIMPULAN}

Model pembelajaran yang dapat diterapkan dalam pengajaran bahasa Inggris pada kelompok belajar buta aksara serta efektif dan cocok dengan karakteristik di Mulyasari adalah TPR (Total Physical Response). Tim juga menilai perlu dilakukan pelatihan berkesinambungan bagi para relawan tenaga didik agar dapat menguasai berbagai model pembelajaran bahasa Inggris. Peningkatan mutu pendidikan juga ditentukan oleh pengajar atau pendidik, sehingga guru masa depan dibentuk untuk lebih aktif dalam menggunakan berbagai model pembelajaran lainnya pada bidang lainnya pula. Semua ini tentunya pekerjaan rumah serta panggilan kesadaran untuk berbagi pengetahuan dengan saudarasaudara kita yang kurang beruntung. Di atas apapun, komitmen dan ketulusan merupakan kunci dalam pelaksanaan kegiatan ini. 


\section{UCAPAN TERIMA KASIH}

Ucapan terima kasih Tim sampaikan kepada Ustadz Sholeh yang dengan gigih memperjuangkan pendidikan bagi anak-anak di Mulyasari, Bapak Wisnu sebagai ketua komunitas $1001 \mathrm{Ilmu}$, serta semua relawan yang berkomitmen dalam pendidikan.

\section{DAFTAR PUSTAKA}

BPS. (2006). Badan Pusat Statistik. Retrieved from https://www.bps.go.id/subject/28/pendidikan.html

Dwi Atmanti, H. (2005). Investasi sumber daya manusia melalui pendidikan. Jurnal Dinamika Pembangunan (JDP), 2(Nomor 1), 30-39.

Erwinandari, D. (2013). A Descriptive Study On Teaching Reading Descriptive Text To The First Year Student Of SMK Negeri Pringkuku Pacitan In 2012-2013 Academic Year. Skripsi. Retrieved from http://studiamsu.eu/wp-content/uploads/30.-p.144148.pdf

Ikhwati, A., \& Megawati, E. (2018). Efektivitas Model Pembelajaran TPR (Total Physical Response) dalam Pengajaran Bahasa Inggris. Deiksis, 10(1), 11-19. https://doi.org/10.30998/deiksis.v10i01.1937

Jacobs, G. M., \& Farrell, T. S. C. (2003). Understanding and implementtng the CLT (Communicative Language Teaching) paradigm. RELC Journal, 34(1), 5-30.

Kosim, M. (2012). Urgensi Pendidikan Karakter. KARSA: Journal of Social and Islamic Culture, 19(1), 84-92.

Larsen, D., \& Freeman. (1986). Techniques and Principles in Language Teaching. Oxford: Oxford University Press.

Mart, C. T. (2013). The Audio-Lingual Method: An Easy way of Achieving Speech. International Journal of Academic Research in Business and Social Sciences, 3(12), 63-65. https://doi.org/10.6007/ijarbss/v3-i12/412

Megawati, E. (2019). Penggunaan Model Pembelajaran Peer Teaching dalam Pengajaran Tenses pada Mahasiswa EFL. Deiksis, 11(01), 39. https://doi.org/10.30998/deiksis.v11i01.3076

Natsir, M., \& Sanjaya, D. (2014). Grammar Translation Method (GTM) Versus Communicative Language Teaching (CLT); A Review of Literature. International Journal of Education and Literacy Studies, 2(1), 58-62. https://doi.org/10.7575/aiac.ijels.v.2n.1p.58

Perdana, N. S. (2015). Faktor-Faktor yang Berpengaruh Terhadap Aksesibilitas Memperoleh Pendidikan untuk Anak-Anak di Indonesia. Jurnal Pendidikan Dan Kebudayaan, 21(3), 279-297. https://doi.org/10.24832/jpnk.v21i3.191

Richards, \& Rodgers. (1986). The approaches and methods in language teaching. Cambridge: CUP.

Sahputra, A. (2014). Peran UNESCO dalam Pemberantasan Buta Aksara di Indonesia Tahun 2007-2012. Jom Fisip, 1(2), 1-11. 
https://doi.org/10.1017/cbo9781107415324.004

Sudarsana, I. K. (2018). Membentuk Karakter Anak Sebagai Generasi Penerus Bangsa Melalui Pendidikan Anak Usia Dini. Jurnal Purwadita, 1(1). Retrieved from http://jurnal.stahnmpukuturan.ac.id/index.php/Purwadita/article/download/8/7

UU No. 20 Tahun 2003. (2003). Undang-undang Republik Indonesia nomor 20 tahun 2003 tentang sistem pendidikan nasional. Retrieved from https://peraturan.bkpm.go.id/jdih/userfiles/batang/UU_20_2003.pdf

Wuryandani, D. (2014). Peluang dan tantangan SDM Indonesia menyongsong era masyarakat ekonomi asean. Info Singkat Ekonomi Dan Kebijakan Publik. Vol. VI, (17), 13-16. 